\title{
STUDI TENTANG KETERCAPAIAN KOMPETENSI SISWA PADA MATERI PENGISIAN REFRIGERAN DI UNIT TATA UDARA DOMESTIK
}

\author{
Yulan E. Pramudita ${ }^{1}$, Kamin Sumardi ${ }^{2}$, Ega T. Berman ${ }^{3}$ \\ Universitas Pendidikan Indonesia \\ JL. Dr. Setiabudhi No. 229, Bandung 40154 \\ yulanpramudita@gmail.com
}

\begin{abstract}
ABSTRAK
Penelitian ini bertujuan untuk mengetahui sejauh mana ketercapaian kompetensi siswa di aspek kognitif (pengetahuan), afektif (sikap kerja), dan psikomotor (keterampilan) pada materi pengisian refrigeran di unit tata udara domestik. Penelitian ini menggunakan metode deskriptif yang dilakukan di SMK Negeri 1 Cimahi, subjek penelitian adalah kelas XI TPTU dengan sampel berjumlah 21 siswa. Instrumen penelitian yang digunakan adalah tes tertulis dengan jenis pilihan ganda untuk mengetahui ketercapaian kognitif, dan lembar observasi berupa Standar Operasional Prosedur dan proses kerja praktek. Hasil penelitian menunjukkan ketercapaian kompetensi siswa pada aspek kognitif termasuk ke dalam predikat cukup, pada aspek afektif termasuk ke dalam predikat cukup, dan pada aspek psikomotor termasuk ke dalam predikat baik.
\end{abstract}

Kata kunci: ketercapaian, kompetensi, pengisian refrigeran.

\section{PENDAHULUAN}

Pendidikan pada hakikatnya adalah suatu proses membina sumber daya manusia (SDM) untuk mengembangan potensi diri yang dimilikinya. Pendidikan adalah suatu usaha sadar dan terencana untuk mewujudkan proses pembelajaran agar peserta didik secara aktif mengembangkan potensi dirinya untuk memiliki kekuatan spiritual keagamaan, pengendalian diri, kepribadian, kecerdasan, akhlak mulia, serta keterampilan yang diperlukan dirinya, masyarakat, bangsa dan negara. UU No.20 tahun 2003 tentang Sistem Pendidikan Nasional menyatakan bahwa: Sekolah Menengah Kejuruan (SMK) yang memiliki tujuan utama untuk menciptakan SDM yang kompeten, profesional, dan berdisiplin yang tinggi sehingga mampu bersaing di dunia kerja. Tujuan khusus SMK adalah menyiapkan siswa agar menjadi manusia produktif, mampu bekerja mandiri, dan mengisi lowongan pekerjaan yang ada di dunia usaha dan dunia industri sebagai tenaga kerja tingkat menengah sesuai dengan kompetensi dalam program keahlian yang dipilihnya.

Standar Kompetensi Kerja Nasional Indonesia (SKKNI) digunakan sebagai acuan dalam pembinaan, persiapan SDM yang berkualitas, dan komponen yang diakui oleh seluruh pemangku kepentingan yang berlaku secara nasional. Pada SKKNI sub sektor bidang pemeliharaan dan perbaikan untuk teknisi lemari pendingin/mesin pengkondisian

\footnotetext{
${ }^{1}$ Mahasiswa Dapartemen Pendidikan Teknik Mesin FPTK UPI

${ }^{2}$ Dosen Dapartemen Pendidikan Teknik Mesin FPTK UPI

${ }^{3}$ Dosen Dapartemen Pendidikan Teknik Mesin FPTK UPI
} 
udara, menjelaskan beberapa kompetensi yang harus dimiliki oleh siswa sebagai calon teknisi sertifikat II. Lulusan SMK bidang keahlian Teknik Pendingin dan Tata Udara disiapkan untuk menjadi teknisi sertifikat II, maka siswa harus menguasai seluruh kompetensi yang terdapat pada SKKNI.

Salah satu elemen kompetensi yang ada adalah memperbaiki perangkat lemari pendingin atau pengkondisian udara, pada kompetensi utama tersebut terdapat beberapa elemen kompetensi. Elemen kompetensi tersebut adalah sebagai berikut: 1) menyiapkan perbaikan; 2) memperbaiki kelistrikan dan fungsi remote control; 3) memperbaiki sistem pendingin/ cooling system (menambah refrigeran); 4) memperbaiki sistem pendinginan/ cooling system/ mengisi ulang refrigeran; 5) elaporkan hasil perbaikan.

Siswa harus menguasai setiap elemen kompetensi yang ada, sehingga dapat memenuhi tuntutan pekerjaan. Elemen kompetensi mengisi ulang refrigeran di unit tata udara domestik dikatakan penting untuk siswa pahami dengan baik dan benar dari segi pengetahuan, Standar Operasional Prosedur (SOP), dan langkah kerja. Pada proses perbaikan dengan mengisi ulang refrigeran di unit tata udara domestik sering terjadi, karena untuk setiap perbaikan pemipaan dan kebocoran yang terjadi dapat dipastikan unit akan diisi kembali dengan refrigeran yang baru.

Seluruh elemen kompetensi pada SKKNI tersebut dipelajari pada mata pelajaran produktif di SMK bidang keahlian Teknik Pendingin dan Tata Udara. Salah satu mata pelajarannya adalah Sistem dan Instalasi Tata Udara di kelas XI. Pada mata pelajaran ini terdapat Kompetensi Dasar (KD) mengenai prosedur pemasangan unit AC Split. Materi pada KD ini membahas tentang prosedur penempatan unit, pemasangan unit indoor dan outdoor, hingga proses evakuasi dan pengisian refrigeran ke dalam sistem. Setelah mempelajari setiap materi tersebut siswa dituntut untuk kompeten dalam pemasangan unit tata udara domestik sesuai dengan prosedur yang ada.

Ketercapaian kompetensi siswa dapat dilihat dari aspek kognitif, afektif, dan psikomotor. Aspek kognitif mencakup pemahaman dan pengetahuan siswa tentang materi yang dipelajari. Aspek afektif mencakup sikap kerja yang dinilai dari penggunaan alat dan bahan sesuai, penggunaan alat keselamatan kerja, dan langkah-langkah kerja yang dilakukan sesuai dengan SOP. Sedangkan aspek psikomotor mencakup langkah kerja yang dilakukan saat melakukan kerja praktek. Penilaian setiap materi pada setiap aspek kompetensi dibutuhkan untuk melihat kesulitan dan kekurangan pahaman siswa, sehingga siswa dapat terus terpantau agar kompetensi secara keseluruhan tercapai. 
Salah satu materi yang harus diukur untuk mengetahui ketercapaian siswa adalah pada materi pengisian refrigeran, dimana materi ini termasuk ke dalam KD pemasangan unit tata udara domestik. Materi ini relevan dengan salah satu elemen kompetensi SKKNI yang harus dimiliki oleh setiap siswa lulusan SMK Bidang Studi Teknik Pendingin dan Tata Udara. Hasil pengamatan peneliti di SMK Negeri 1 Cimahi bidang keahlian Teknik Pendingin dan Tata Udara, didapat beberapa gambaran umum sebagai berikut: ketersediaan unit AC Split yang terdapat di workshop sebanyak delapan unit yang dibagi untuk dua kelas, sedangkan jumlah siswa yang melakukan praktik pengisian refrigeran dalam satu waktu 16 siswa dari dua kelas. Dengan demikian, rasio antara unit dengan siswa saat praktik adalah 1:2. Praktik pengisian refrigeran di unit AC Split hanya dilakukan satu kali oleh setiap kelompok siswa sehingga dirasa tidak cukup untuk bisa membuat siswa kompeten secara maksimal. Belum adanya penilaian praktek pada materi pengisian refrigeran, dimana penilaian praktek adalah penilaian dari keseluruhan KD pemasangan AC Split.

Kondisi yang dipaparkan di atas menyebabkan proses pembelajaran menjadi kurang optimal. Akibatnya adalah tidak optimalnya penguasaan keterampilan pada materi pengisian refrigeran di unit tata udara domesti oleh siswa terutama pada aspek psikomotor. Hal ini diperkuat dengan hasil wawancara dengan Guru pengampu yang dinyatakan bahwa tingkat penguasaan kompetensi materi pengisian refrigeran di unit AC Split pada aspek psikomotor masih belum optimal.

Pada penelitian terdahulu, ditemukan masalah jika mahasiswa kesulitan mencapai kompetensi dari suatu materi. Kesulitan tersebut dikarenakan kurangnya sarana dan prasarana, serta tenaga pengajar yang tidak sepadan dengan jumlah mahasiswa. Penilaian kecetercapaian kompetensi harus dilakukan secara rinci, hal ini dibutuhkan untuk dapat memantau kemampuan objek yang diteliti (Wijaya, 2015). Ketercapaian kompetensi siswa dapat diukur sehingga dapat diketahui hasil belajar yang didapatkan oleh siswa. Hasil dari ketercapaian kompetensi siswa dapat menggambarkan tingkat keefektifan suatu proses pembelajaran, maka guru harus lebih meningkatkan kualitas proses pembelajaran agar hasil belajar semakin optimal (Widihastuti, 2007).

\section{METODE PENELITIAN}

Metode penelitian ini adalah metode penelitian deskriptif, dimana peneliti akan memotret ketercapaian siswa pada materi pengisian refrigeran di unit tata udara domestik. Terdapat beberapa komponen penilaian yang harus dipenuhi siswa dalam penelitian ini, 
yaitu: aspek pengetahuan yang dinilai dari pengetahuan siswa dalam menjelaskan fungsi refrigeran, definisi evakuasi sistem, cara melakukan evakuasi sistem, dan cara melakukan pengisian refrigeran di unit tata udara. Aspek sikap kerja yang dinilai dari penggunaan alat dan bahan sesuai, penggunaan alat keselamatan kerja, dan langkah-langkah kerja yang dilakukan sesuai dengan Standar Operasional Prosedur (SOP).

Aspek keterampilan yang dilihat dari praktek pengisian refrigeran di unit tata udara domestik. Kriteria dalam komponen penilaian adalah sebagai berikut: kKomponen penilaian membaca spesifikasi unit serta menyiapkan alat dan bahan dilihat dari pemahaman membaca spesifikasi unit serta persiapan alat dan bahan yang dilakukan oleh siswa. Komponen penilaian menggunakan alat keselamatan kerja dilihat dari penggunaan alat keselamatan kerja dengan baik dan benar yang dilakukan oleh siswa. Komponen penilaian langkah kerja dilihat dari proses kerja sesuai SOP yang dilakukan oleh siswa. Komponen penilaian hasil kerja dilihat dari unit tata udara domestik terisi refrigeran dengan tekanan yang sesuai dengan buku petunjuk dari unit.

\section{HASIL PENELITIAN}

Penelitian pada aspek kognitif berupa tes tulis berjumlah 22 butir soal. Hasil yang didapatkan (Tabel 1) bahwa rata-rata ketercapaian kompetensi pada aspek kognitif ini adalah sebesar 74\%, dan rata-rata nilai yag didapatkan adalah 2,21.

Tabel 1. Hasil tes tulis pada aspek kognitif

\begin{tabular}{clccc}
\hline No. & \multicolumn{1}{c}{ Sub Komponen } & $\begin{array}{c}\text { Skor } \\
\text { Maksimal }\end{array}$ & $\begin{array}{c}\text { Perolehan } \\
\text { Skor }\end{array}$ & Persentase \\
\hline 1 & $\begin{array}{l}\text { Menjelaskan pengertian dan } \\
\text { karakteristik refrigeran (C1) }\end{array}$ & 42 & 32 & 76,2 \\
2 & $\begin{array}{l}\text { Menyebutkan jenis dan warna tabung } \\
\text { refrigeran (C1) }\end{array}$ & 84 & 56 & 66,7 \\
3 & $\begin{array}{l}\text { Menjelaskan evakuasi sistem (C1) } \\
4\end{array}$ & 21 & 19 & 90,5 \\
5 & $\begin{array}{l}\text { Menghitung tekanan pada sistem (C3) } \\
\text { Menyebutkan alat yang digunakan } \\
\text { pada proses memvakum sistem dan } \\
\text { mengisi refrigeran (C1) }\end{array}$ & 84 & 61 & 72,6 \\
6 & $\begin{array}{l}\text { Menunjukkan langkah pengisian } \\
\text { refrigeran di unit tata udara domestik } \\
\text { (C3) }\end{array}$ & 105 & 83 & 79,1 \\
\hline & $\quad$ Jumlah/Rata-rata & 462 & 90 & 71,4 \\
\hline
\end{tabular}


Tabel 2. Hasil Observasi pada Aspek Afektif

\begin{tabular}{rlccc}
\hline No. & \multicolumn{1}{c}{ Komponen/ Sub Komponen } & $\begin{array}{c}\text { Skor } \\
\text { Maksimal }\end{array}$ & $\begin{array}{c}\text { Perolehan } \\
\text { Skor }\end{array}$ & Persentase \\
\hline \multirow{2}{*}{1} & Persiapan kerja & & & \\
& $\begin{array}{l}\text { 1.1 Membaca spesifikasi unit } \\
\text { 1.2 Pesiapan alat dan bahan }\end{array}$ & 21 & 15 & 71,4 \\
2 & $\begin{array}{l}\text { Penggunaan alat K3 } \\
\text { Menggunakan alat K3 }\end{array}$ & 126 & 130 & 56,3 \\
& $\begin{array}{l}\text { Langkah kerja } \\
3\end{array}$ & & 44 & 34,9 \\
3.1 Evakuasi sistem & 21 & 21 & 100 \\
3.2 Pengisian refrigeran & 84 & 71 & 84,5 \\
\hline
\end{tabular}

Tabel 3. Hasil Observasi pada Aspek Psikomotor

\begin{tabular}{|c|c|c|c|c|}
\hline No & Komponen/ Sub Komponen & $\begin{array}{l}\text { Maksimum } \\
\text { Skor }\end{array}$ & $\begin{array}{l}\text { Perolehan } \\
\text { Skor }\end{array}$ & Persentase \\
\hline \multirow{3}{*}{1} & Persiapan kerja & & & \\
\hline & 1.1 Membaca spesifikasi unit & 21 & 15 & 71,4 \\
\hline & 1.2 Pesiapan alat dan bahan & 231 & 151 & 65,4 \\
\hline \multirow{2}{*}{2} & Penggunaan alat K3 & & & \\
\hline & $\begin{array}{l}\text { Menggunakan alat K3 } \\
\text { Langkah kerja }\end{array}$ & 126 & 44 & 34,9 \\
\hline \multirow[t]{2}{*}{3} & 3.1 Evakuasi sistem & 210 & 210 & 100 \\
\hline & 3.2 Pengisian refrigeran & 357 & 300 & 83,8 \\
\hline \multirow[t]{2}{*}{4} & Hasil Kerja & 84 & 67 & 81 \\
\hline & Jumlah & 1029 & 784 & \\
\hline
\end{tabular}

\section{PEMBAHASAN}

Seluruh sub komponen belum mencapai persentase yang sempurna, terutama pada sub komponen jenis-jenis refrigeran (Tabel 1). Jika siswa kurang menguasai materi pengisian refrigeran, maka dapat dikatakan hasil belajarnya belum optimal. Hasil belajar merupakan bagian terpenting dalam pembelajaran. Hasil belajar siswa pada hakikatnya adalah perubahan tingkah laku sebagai hasil belajar dalam pengertian yang lebih luas mencakup bidang kognitif, afektif, dan psikomotorik (Sudjana, 2009). Hasil belajar merupakan hasil dari suatu interaksi tindak belajar dan tindak mengajar. Proses belajar dan mengajar yang baik dan efisien juga proses evakuasi hasil belajar yang baik pula akan berdampak pada hasil belajar yang optimal. Jika hasil belajar belum optimal, maka proses belajar mengajar juga dikatakan belum baik dan efisien. Sehingga harus adanya perbaikan pola mengajar seperti penggunaan metode pembelajaran yang lebih bervariasi. Penilaian hasil belajar juga harus dilakukan dengan baik dan benar secara detil sehingga guru dapat terus memantau ketercapaian kompetensi siswa pada aspek kognitif. 
Instrumen penelitian berupa observasi checklist untuk mengetahui ketercapaian kompetensi pada aspek afektif. Penilaian pada lembar observasi berupa skor, dimana setiap indikator yang dilakukan dengan benar akan mendapatkan skor (satu). Jika indikator tidak dilakukan, maka tidak akan mendapatkan skor (nol). Skor maksimum dari penilaian aspek afektif adalah sebesar dua puluh tiga. Rata-rata persentase ketercapaian kompetensi pada aspek afektif adalah sebesar 58,2\%, dan rata-rata nilai adalah sebesar 2,33.

Data pada Tabel 2. menunjukkan persentase dari yang paling rendah adalah pada sub kompetensi menggunakan alat K3, persiapan alat dan bahan, dan sub kompetensi membaca spesifikasi unit. Saat melakukan kerja praktik, siswa harus melakukan persiapan kerja dengan membaca spesifikasi unit serta menyiapkan alat dan bahan. Namun kenyataannya masih ada siswa yang tidak membaca spesifikasi unit terlebih dahulu. Padahal sub komponen tersebut harus dilakukan sebelum melakukan praktik untuk mengetahui spesifikasi unit. Hal ini sangat diperlukan karena tidak semua merk AC split memiliki spesifikasi yang sama.

Sub komponen persiapan alat dan bahan terlihat persentase keterlaksanaannya yang cukup rendah. Siswa seharusnya menyiapkan seluruh alat dan bahan yang akan digunakan. Namun pada kenyataannya tidak semua alat tersedia di sekolah, yang paling terlihat jelas adalah tidak tersedianya alat keselamatan kerja seperti sarung tangan, kacamata safety, dan masker. Selain itu, alat pendeteksi kebocoran (halide leak detector) juga tidak dimiliki oleh jurusan. Hal tersebut mengakibatkan tidak ada satupun siswa yang menggunakannya saat praktik. Sepatu safety juga hanya digunakan oleh enam orang siswa.

Pada sub komponen evakuasi sistem pada langkah kerja praktik, didapat hasilnya sempurna untuk evakuasi sistem. Hasil tersebut terjadi karena siswa dapat menentukan tekanan sistem dalam kondisi vakum yang ditunjukkan oleh manifold gauge dengan baik dan benar tanpa menemukan kendala.

Penilaian pada aspek psikomotor dilakukan dengan menggunakan lembar observasi yang indikatornya lebih rinci dari setiap sub komponen. Terdapat empat puluh sembilan indikator pada lembar observasi ini. Data aspek psikomotor pada komponen persiapan kerja dan penggunaan alat K3 sama dengan data pada aspek afektif. Untuk sub komponen langkah kerja, indikator yang ada lebih rinci dimana terdapat sepuluh indikator pada sub komponen evakuasi sistem, dan tujuh belas indikator pada pengisian refrigeran. Data hasil penelitian secara keseluruhan pada aspek ini dipaparkan pada Tabel 3.

Data pada aspek psikomotor untuk sub komponen yang menempati posisi terendah dan tertinggi persentasenya sama dengan data pada aspek afektif. Dimana pada komponen 
penggunaan alat keselamatan kerja sangat rendah persentase dikarenakan alat keselamatan kerja yang tidak disediakan oleh pihak jurusan. Sedangkan pada langkah kerja evakuasi sistem, seluruh siswa dapat melakukan langkah kerja dengan baik dan benar sehingga didapatkan hasil yang sempurna. Siswa dapat menentukan tekanan sistem dalam kondisi vakum yang ditunjukkan oleh manifold gauge dengan baik dan benar tanpa menemukan kendala.

Elemen kompetensi pengisian refrigeran adalah salah satu dari enam elemen kompetensi yang ada pada kompetensi memperbaiki perangkat mesin pengkondisian udara. Seluruh indikator yang ada harus dilakukan dengan baik dan benar, sehingga siswa dapat dikatakan kompeten dan memiliki keterampilan pada elemen kompetensi pengisian refrigeran di unit tata udara domestik. Pada silabus yang terdapat disekolah, materi pengisian refrigeran terdapat pada kompetensi dasar pemasangan unit AC Split. Penilaian aspek psikomotor yang ada adalah penilaian praktik pemasangan unit AC Split secara keseluruhan, padahal pada kompetensi dasar tersebut terdapat beberapa materi yang seharusnya dilakukan penilaian secara lebih rinci. Hal tersebut dilakukan agar dapat mengetahui tingkat keterampilan siswa pada setiap materi demi menunjang ketercapai kompetensi dasar secara keseluruhan (Winata, 2016).

Pada kondisi dilapangan, praktik pengisian refrigeran di unit tata udra domestik hanya dilakukan satu kali oleh siswa. Hal ini yang membuat siswa belum dapat dikatakan kompeten atau terampil karena masih terdapat kekurangan pada proses praktik. Seharusnya praktik tersebut dilakukan lebih dari satu kali hingga siswa dikatakan kompeten dan terampil dalam pengisian refrigeran di unit tata udara domestik. Keterampilan yang dimiliki siswa harus terus dilatih. Keterampilan yang dilatih melalui praktik secara berulang-ulang akan menjadi kebiasaan atau otomatis dilakukan (Depdiknas, 2008). Latihan yang dilakukan berulang-ulang akan memberikan pengaruh yang sangat besar pada pemahiran keterampilan siswa.

\section{KESIMPULAN}

Pada bagian ini penulis menguraikan kesimpulan dari data penelitian yang telah di analisis. Pencapaian kompetensi siswa kelas XI Teknik Pendingin dan Tata udara kelas XI di SMK Negeri 1 Cimahi, sebagai berikut: ketercapaian kompetensi siswa pada aspek kognitif termasuk ke dalam predikat cukup, dimana hampir seluruh siswa dinyatakan pada predikat cukup kompeten. Ketercapaian kompetensi siswa pada aspek afektif termasuk ke 
dalam predikat cukup, dimana hampir seluruh siswa dinyatakan kompeten pada predikat cukup. Ketercapaian kompetensi siswa pada aspek psikomotor termasuk ke dalam predikat baik, dimana lebih dari sebagian besar siswa dinyatakan kompeten pada kategori baik.

\section{REFERENSI}

Depdiknas (2008). Kurikulum Tingkat Satuan Pendidikan. Jakarta: Depdiknas.

Sudjana. (2009). Penilaian Hasil Proses Belajar Mengajar. Bandung: Remaja Rosdakarya.

Wijaya. (2015). Ketercapaian Kompetensi Las TIG Level $1 \mathrm{G}$ pada Perkuliahan Teknik Pengelasan. Journal of Mechanical Engineering Education, (2) 2, hlm.258-267.

Widihastuti. (2007). Pencapaian Standar Kompetensi Siswa SMK Negeri Program Keahlian Tata Busana di Kota Yogyakarta dalam Pembelajaran dengan KBK. Jurnal Penelitian dan Evaluasi Pendidikan (2), hlm.268-278.

Winata. (2016). Pengaruh Kompetensi Kejuruan dan Motivasi Memasuki Dunia Kerja terhadap Kesiapan Kerja Siswa Kelas XII SMK Negeri 1 Ambal Tahun Pelajaran 2015/ 2016. Jurnal Pendidikan Teknik Otomotif. (8) 1. 